\title{
Procedure Intended Dose Regimen
}

National Cancer Institute

\section{Source}

National Cancer Institute. Procedure Intended Dose Regimen. NCI Thesaurus. Code C117523.

A treatment plan that specifies the amount, schedule, and the duration of the procedure. 